\title{
IL-4 and IL-13 regulate TLR expression and eosinophil-basophil differentiation of cord blood $\mathrm{CD}_{4}{ }^{+}$progenitor cells
}

\author{
Pia Reece ${ }^{1 *}$, Gail M Gauvreau', Roma Sehmi², Judah A Denburg ${ }^{1}$ \\ From Canadian Society of Allergy and Clinical Immunology Annual Scientific Meeting 2014 \\ Ottawa, ON, Canada. 23-26 October 2014
}

\section{Background}

Intrauterine environmental exposures have been shown to influence neonatal immunity and subsequent allergic disease development [1]. We have previously shown that cord blood (CB) progenitor cells of high atopic risk infants have reduced toll-like receptor (TLR) expression and produce fewer lipopolysaccharide (LPS)-stimulated eosinophil-basophil (Eo/B) colonies, compared to lowatopic risk infants. In the present study, we investigated whether a surrogate ex vivo $\mathrm{T}_{\mathrm{H}} 2$ milieu (i.e., either IL-4 or IL-13), could represent an underlying mechanism to explain our previous findings.

\section{Methods}

$\mathrm{CB} \mathrm{CD} 34^{+}$cells from healthy donors were cultured with IL-4 or IL-13 (in combination with LPS) and assessed for TLR-2, TLR-4, and TLR-9 expression using flow cytometry, as well as Eo/B differentiation using methylcellulose cultures. Pharmacological inhibitors were added to the methylcellulose cultures to determine the effect of blocking IL-4 or IL-13 signalling in CB CD34 ${ }^{+}$ cells in relation to Eo/B colony forming unit (CFU) formation.

\section{Results}

Stimulation of CD34 ${ }^{+}$cells with IL- 4 or IL-13 trended to decreased expression of TLR-2 $(\mathrm{p}=0.063)$, whereas IL-4, but not IL-13, reduced Eo/B CFU formation in the presence of LPS. The latter was found to be dependent on IL-4R $\alpha$ and not IL-13R $\alpha 1$.

\section{Conclusions}

Thus, the responsiveness of $\mathrm{CB} C D 34^{+}$progenitor cells to LPS is differentially regulated by the $\mathrm{T}_{\mathrm{H}} 2$ cytokines, IL- 4 and IL-13, and may be related to TLR expression on these cells. Therefore, in utero interactions between placental-derived pro-allergic cytokines and neonatal progenitor cells influences $\mathrm{CD} 34^{+}$phenotype and function, with implications for Eo/B-mediated inflammatory responses in early life.

\section{Authors' details}

'Division of Clinical Immunology and Allergy, McMaster University, Hamilton, Ontario Canada, L8S 4K1. ${ }^{2}$ Asthma Research Group, Firestone Institute for Respiratory Health, McMaster University Hamilton, Ontario, Canada L8N 4A6.

Published: 18 December 2014

\section{Reference}

1. Hinz D, Bauer M, Roder S, Olek S, Huehn J, Sack U, Borte M, Simon JC, Lehmann I, Herberth G, for the LINA study group: Cord blood Tregs with stable FOXP3 expression are influenced by prenatal environment and associated with atopic dermatitis at the age of one year. Allergy 2012, 67:380-389.

doi:10.1186/1710-1492-10-S2-A60

Cite this article as: Reece et al:: IL-4 and IL-13 regulate TLR expression and eosinophil-basophil differentiation of cord blood $\mathrm{CD} 34^{+}$progenitor cells. Allergy, Asthma and Clinical Immunology 2014 10(Suppl 2):A60.

\footnotetext{
* Correspondence: reecep@mcmaster.ca

'Division of Clinical Immunology and Allergy, McMaster University, Hamilton, Ontario Canada, L8S 4K1

Full list of author information is available at the end of the article
} 